Egyptian Journal of Aquatic Biology and Fisheries

Zoology Department, Faculty of Science,

Ain Shams University, Cairo, Egypt.

ISSN $1110-6131$

Vol. 25(1): 313 - 329 (2021)

www.ejabf.journals.ekb.eg

\title{
Effect of shrimp waste extracted chitin on growth and some biochemical parameters of the Nile tilapia
}

\author{
Sabry S. Elserafy, Nassr-Allah H. Abdel-Hameid,* Hany A. Abdel-Salam, Ali M. Dakrouni \\ Department of Zoology, faculty of Science, Benha University, Benha, Egypt \\ "Corresponding author: Nassr65@gmail.com
}

\begin{abstract}
ARTICLE INFO
Article History:

Received: Jan. 9, 2021

Accepted: Jan. 18, 2021

Online: Jan. 26, 2021
\end{abstract}

\section{Keywords:}

chitin,

probiotic,

O. niloticus,

growth,

biochemical parameters

\section{INTRODUCTION}

\section{ABSTRACT}

In this study, four groups of Nile tilapia (O.niloticus) were fed diets in which chitin substituted cellulose (present in basal diet) by $0,2 \%, 5 \%$ and $10 \%$. Another 4 groups were fed the same diets with the addition of $1 \mathrm{~g}$ probiotic $/ \mathrm{kg}$ diet. The group fed $10 \%$ chitin + probiotic had the best growth performance parameters and feed conversion ratio (FCR). Condition factor $(\mathrm{K})$ was optimal for the fish fed the highest chitin concentration with probiotic in addition to the control group. The group fed $10 \%$ chitin+probiotic exhibited a significant increase in the final weight, weight gain, and weight gain $\%$ over $0,2,10 \%$ chitin and $0 \%$ chitin+probiotic groups. The control and the group fed $10 \%$ chitin with probiotic have the highest $\mathrm{K}$. They have significantly increased $\mathrm{K}$ values over $2 \%, 5 \%$ chitin groups and the probiotic groups $(0,2,5 \%$ chitin + probiotic $)$. Aspartate aminotransferase and alanine aminotransferase activities in fish homogenate were not significantly changed between all groups. Catalase (CAT) activity was increased significantly in 5\% chitin+probiotic group overall groups. The group fed $10 \%$ chitin with probiotic has the lowest catalase which was non significantly changed in most groups. Also, Glutathione was increased significantly in the groups fed $2 \%$ chitin+probiotic and $10 \%$ chitin+probiotic over those of the control and 5\% chitin. It was increased significantly in the groups fed the basal diet either supplemented with probiotics or supplemented with $5 \%$ chitin + probiotic over the control. Similarly, the total protein was significantly increased in $10 \%$ chitin group over all other groups. Its content in the control, $2 \%$ chitin and $5 \%$ chitin groups were significantly increased overall groups fed probiotic diet. Therefore, and based on the presented data, worthy to recommend the use of chitin as an aquafeed additive in aquaculture.

Capture fisheries is the utilization of the usable aquatic organisms by the public with or without permissions (El-Sayed, 2006). Aquaculture is the farming of marine and freshwater organisms under controlled conditions. It is a highly growing food production sector (Ahmed and Thompson, 2019). Its global production of fish in 2018 was approximately 179 million tons (FAO, 2020). Farmed Fish are a chief source of food for poor people (Stead, 2019). It is a cheap form of animal protein (Nölle et al., 2020). Due to overfishing, fisheries stock worldwide is largely exploited. As the aquaculture become the main source to cope the fish demand, there is an awareness to increase its productivity with the increase of human population (Tidwell and Allan, 2001; Gephart et al., 2020). Tilapia is regarded as the second most farmed fish all-over the world 
after carp. Its global production is increased significantly in the past decade because of its eligibility for farming, marketability and steady market prices (Wang and Lu, 2016; Prabu et al., 2019).

Chitin is the second abundant naturally synthesized polysaccharide biopolymer after cellulose (Croisier and Jérôme, 2013; Barikani et al., 2014; Zhu et al., 2019). It constitutes a considerable quantity of the exoskeleton (shell) construction of crustaceans (Borić et al., 2020). In the environment, there are growing quantities of shell wastes from aquaculture and crustaceans processing industry due to its slow biodegradability (Shahidi and Synowiecki, 1991). Thus, these wastes are considered as important sources of pollution (Deng et al., 2020). Generally, the global annual production of chitin is approximately $10^{10}-10^{12}$ tons (Elieh-Ali-Komi and Hamblin, 2016). Chitin is vital and renewable natural resource (Agboh and Qin, 1997; Ma et al., 2020). Exoskeleton extracted chitin and its derivatives have a wide range of applications due to its biocompatibility (Barikani et $\boldsymbol{a l} ., 2014$ ), biodegradability (Zhu et $\boldsymbol{a l}$., 2019), antimicrobial and antioxidative properties (Ahmad et al., 2020) and reactivity (Younes and Rinaudo, 2015). However, its sources still disposed in the environment in large quantities (Kumar et al., 2018). Consequently, its sources still regarded as underutilized (Ma et al., 2020).

Growth performance as well as the biochemical parameters of fish were used extensively for the evaluation of different fish feed supplements (Sewaka et al., 2019; Fadl et al., 2020). Of the biochemical parameters, transaminases as aspartate aminotransferase (AST) and alanine aminotransferase (ALT) act to convert amino acids to alpha keto acids and therefore reflect transamination activity (Kobayashi et al., 2020). Antioxidant parameters like CAT and glutathione were used to indicate the capacity of free radical scavenging for fish as well as other animals (Silva et al., 2018; Habashy et al., 2019).

Previous studies used chitin as a feed supplement for different fish species (Ringø et al., 2012). It has been estimated that its digestibility in the gastrointestinal tract of cod fish (Gadus morhua) reach up to $90 \%$. Also, it has chitinase activity in their gastrointestinal tract (Danulat, 1987). Moreover, it has been approved that juvenile cobia (Rachycentron canadum) has chitinolytic activity in their gastrointestinal tract. Therefore, they can digest chitin without the aid of gut microflora (Fines and Holt, 2010). Chitin supplementation in the diet of different fish species (Yellowtail, sea bream and Japanese eel) elevates growth rate and feed efficiencies (Kono et al., 1987). For tilapia, Shiau and Yu (1999) ascertain that growth performance and diet ingredient digestibility of hybrid tilapia ( $O$. niloticus $\mathrm{x} O$. aureus) fingerlings are inversely proportional to the increase of added chitin in diets. In contrast, chitinase activity has been measured and approved in the gastrointestinal tract and serum of O. niloticus (Molinari et al., 2007). Therefore, the present study was conducted to investigate the efficiency of using exoskeleton extracted chitin as a feed supplement for tilapia aquaculture. The aim also extends to improve the exoskeleton extracted chitin as feed supplement through the probiotic supplementation. This also aims to increase the utilization of exoskeleton waste and minimize environmental pollution.

\section{MATERIALS AND METHODS}

\section{Chitin extraction:}

The source of chitin was exoskeleton wastes of shrimp. It was obtained from El-Obour market, Qalubia, Egypt. Chitin was extracted according to Abdou et al. (2008) with some modifications as the following: 
1- Preparation of exoskeleton wastes for chitin chemical extraction:

The hard exoskeleton parts which contains chitin was purified from fleshy parts by hand, washed thoroughly in water, desiccated in room temperature and cut into small bits using home blender.

2- Chemical extraction was carried on $30 \mathrm{~g}$ of crushed material. The following steps were performed:

A- Demineralization: of crushed material was carried out at room temperature using $1 \mathrm{M}$ $\mathrm{HCl}$ acid bath with vigorous shaking many times for 2 days.

B- Deproteinization: was performed using $1 \mathrm{M} \mathrm{NaOH}$ solution bathes at $120^{\circ} \mathrm{C}$ with vigorous shaking for 1 hour each bath. The number of bathes depend on the clarity of the solution. The sign of protein digestion is the solution clearance of color. Then, the material was washed with distilled water till neutral $\mathrm{pH}$ using $\mathrm{pH}$ meter.

C- Decolorization: The extracted chitin from shrimp exoskeleton wastes is highly pink due to the presence of pigment traces, so that these pigments were removed using $0.1 \mathrm{M}$ $\mathrm{KMnO}_{4}, 0.1 \mathrm{M}$ oxalic acid and $0.1 \mathrm{M} \mathrm{H} \mathrm{SO}_{4}$ which respectively added with shaking. Then, chitin was refluxed in ethanol to eliminate the traces of proteins and pigments. Afterwards, the prepared fluffy white chitin was desiccated in room temperature.

The chemical extraction process was repeated 3 times to calculate the yield of chitin.

The extracted chitin was chemically and physically characterized to approve the success of extraction methodology. The characterization of chitin was performed using Fourier Transform Infrared spectroscopy (FT-IR, Scientific Nicolet iS10, Chemistry department, Faculty of Science, Benha University). FT-IR spectra was recorded in the range of $4000-400 \mathrm{~cm}^{-1}$. Also, it was characterized by scanning electron microscopy (SEM) using (JEOL JEM-100XII SEM, Faculty of Agriculture, Mansoura University) and X-ray diffraction (XRD). X-ray diffraction was measured using X-Pert diffractometer (Central Metallurgical Research and Development Institute, El-Tebbin, Helwan) with $\mathrm{K} \alpha-\mathrm{Cu}$ source $\lambda=154 \mathrm{pm}$. The analysis was recorded for $2 \theta$ in the range $15-80^{\circ}$. The yield percent of chitin was calculated using the following formula:

Chitin yield percent $=($ average weight of prepared chitin $/$ weight of crushed material used $) \times 100$.

\section{Experimental diet formulation}

The composition of the semi-purified diets is shown in Table (1). The fish meal, wheat flour and other solid ingredients were dried at $60^{\circ} \mathrm{C}$ for 12 hours. Solid diet ingredients were well sieved from large parts, bones and spines to obtain well mixing for all diet ingredients. To prepare one $\mathrm{kg}$ of each diet, $520 \mathrm{~g}$ fish meal, $75 \mathrm{~g}$ wheat flour, $250 \mathrm{~g}$ maltose, $10 \mathrm{~g}$ mineral mixture and 10 $\mathrm{g}$ vitamin mixture were mixed. Then $5 \mathrm{~g}$ carboxymethyl cellulose was added to work as a binder to stabilize the feed in water. One hundred $g$ of cellulose was added in the basal diet of the control. Extracted chitin was added to the diets as a replacement of cellulose to keep the ratio of each diet ingredient constant. All ingredients were well mixed to obtain homogeneous mixture. Thirty g of fish oil was mixed with $550 \mathrm{ml}$ distilled water and then were added gradually on the ingredient mixture with vigorous mixing to prepare homogeneous dough. Eight diets were formulated. In the first four of them chitin substitutes cellulose by $0,2,5$, and $10 \mathrm{~g} / 100 \mathrm{~g}$ diet. The other 4 diets were the same serial substitution of cellulose with chitin in addition to $1 \mathrm{~g}$ probiotic/ $\mathrm{kg}$ diet. The composition of the used probiotic was indicated in Table (2). 
Table 1. Experimental diets ingredients and formulation (\% as dry mass)

\begin{tabular}{|c|c|c|c|c|c|c|c|c|}
\hline \multirow[b]{2}{*}{ Groups } & \multirow{2}{*}{$\begin{array}{c}\text { Basal diet } \\
\text { G1 }\end{array}$} & \multicolumn{3}{|c|}{ Chitin without probiotic } & \multirow{2}{*}{$\begin{array}{c}\text { Basal d.+ pro } \\
\text { G5 }\end{array}$} & \multicolumn{3}{|c|}{ Chitin with probiotic } \\
\hline & & G2 & G3 & G4 & & G6 & G7 & G8 \\
\hline Ingredient \% & $\begin{array}{c}\text { Negative } \\
\text { control }\end{array}$ & $\begin{array}{c}2 \% \\
\text { chitin }\end{array}$ & $\begin{array}{c}5 \% \\
\text { chitin }\end{array}$ & $\begin{array}{l}10 \% \\
\text { chitin }\end{array}$ & $\begin{array}{c}\text { Positive } \\
\text { control }\end{array}$ & $\begin{array}{c}2 \% \\
\text { chitin }\end{array}$ & $\begin{array}{c}5 \% \\
\text { chitin }\end{array}$ & $\begin{array}{l}10 \% \\
\text { chitin }\end{array}$ \\
\hline fish meal & 52 & 52 & 52 & 52 & 52 & 52 & 52 & 52 \\
\hline wheat flour & 7.5 & 7.5 & 7.5 & 7.5 & 7.5 & 7.5 & 7.5 & 7.5 \\
\hline Maltose & 25 & 25 & 25 & 25 & 25 & 25 & 25 & 25 \\
\hline Cellulose & 10 & 8 & 5 & $\mathbf{0}$ & 10 & 8 & 5 & $\mathbf{0}$ \\
\hline Chitin & $\mathbf{0}$ & 2 & 5 & 10 & $\mathbf{0}$ & 2 & 5 & 10 \\
\hline fish oil & 3 & 3 & 3 & 3 & 3 & 3 & 3 & 3 \\
\hline mineral mix & 1 & 1 & 1 & 1 & 1 & 1 & 1 & 1 \\
\hline vit. Mix & 1 & 1 & 1 & 1 & 1 & 1 & 1 & 1 \\
\hline $\mathrm{CMC}$ & 0.5 & 0.5 & 0.5 & 0.5 & 0.5 & 0.5 & 0.5 & 0.5 \\
\hline$\%$ & 100 & 100 & 100 & 100 & 100 & 100 & 100 & 100 \\
\hline Probiotic & - & - & - & - & $1 \mathrm{~g} / \mathrm{kg}$ & $1 \mathrm{~g} / \mathrm{kg}$ & $1 \mathrm{~g} / \mathrm{kg}$ & $1 \mathrm{~g} / \mathrm{kg}$ \\
\hline
\end{tabular}

Table 2. PRO - PAC probiotic content (PRO - BYN international Inc, USA)

\begin{tabular}{cccc}
\hline Ingredients & Product specification & Ingredients & Product specification \\
\hline Lactobacillus Acidophilus & $100 \mathrm{~g} / \mathrm{kg}\left(1.0 \times 10^{8} \mathrm{CFU} / \mathrm{gm}\right)$ & Betaine $\mathrm{HCl} 97 \%$ & $100 \mathrm{~g} / \mathrm{kg}$ \\
\hline Bifidacterium bifidum & $2 \mathrm{~g} / \mathrm{kg}\left(2.0 \times 10^{6} \mathrm{CFU} / \mathrm{gm}\right)$ & Xylanase & $12500 \mathrm{Units} / \mathrm{kg}$ \\
\hline Enterococcus faecium & $50 \mathrm{~g} / \mathrm{kg}\left(5.0 \times 10^{7} \mathrm{CFU} / \mathrm{gm}\right)$ & Hemicellulase & $2750 \mathrm{Units} / \mathrm{kg}$ \\
\hline $\begin{array}{c}\text { Lactobacillus planterum } \\
\text { Aspergillus } \text { oryzae fermentation } \\
\text { extracts }\end{array}$ & $4.8 \mathrm{~g} / \mathrm{kg}\left(4.8 \times 10^{7} \mathrm{CFU} / \mathrm{gm}\right)$ & Beta - glucanase & $2250 \mathrm{Units} / \mathrm{kg}$ \\
\hline Cellulase & $50 \mathrm{~g} / \mathrm{kg}$ & Bacillus subtilus \\
fermentation extracts & $50 \mathrm{~g} / \mathrm{kg}$ \\
\hline Protease & $4500 \mathrm{Units} / \mathrm{kg}$ & Alpha Amylase & $25000 \mathrm{Units} / \mathrm{kg}$ \\
\hline
\end{tabular}




\section{Fish and feeding trials}

O. niloticus fry $(0.491 \pm 0.016 \mathrm{~g})$ were obtained from a private aquaculture hatchery (ElAbassa, Abo-Hammad, Sharqueia, Egypt). Acclimation to laboratory conditions was carried out for 3 weeks. Afterwards, the fish frys of apparently similar size were randomly distributed in well aerated 16 glass aquaria as a group of 10 fish/ aquarium. The density of fry was 1 fry/2L. Feeding trials were conducted in duplicated order ( 2 glass aquaria for each group). Thus, the experimental groups were as follows: G1- fed basal diet, G2- fed the basal diet with $2 \%$ chitin, G3- fed the basal diet with $5 \%$ chitin, G4- fed the basal diet with $10 \%$ chitin, G5- fed the basal diet + probiotic, G6fed the basal diet with $2 \%$ chitin + probiotic, G7- fed the basal diet with $5 \%$ chitin + probiotic and G8- fed the basal diet with $10 \%$ chitin + probiotic. The overall initial weight of fish frys in each group was weighed. The fish were fed at a rate of 5\% of their total body weight per day for 11 weeks. The provided feeds were consumed within 30 minutes and no feed remains were observed. Fish were fed twice a day at 10:00 a.m. and 4:00 p.m. Total fish weight per aquarium was determined weekly and feeding rate was adjusted accordingly. The aquarium water was completely exchanged every 3 days as one third was replaced with dechlorinated tap water daily. The photoperiod was adjusted at $12 \mathrm{D}: 12 \mathrm{~L}$ using $24 \mathrm{~h}$ timer. Water temperature for all groups were $24 \pm 2{ }^{\circ} \mathrm{C}$ during the experiment. Survival rate of tilapia fingerlings was estimated for each group at the end of the experiment.

\section{Sample collection and analyses}

\subsection{Growth parameters}

All fish from each aquarium were collected individually at the end of the experiment. Then, every fish was wiped from water curiously by soft tissue and weighed individually by an electronic balance (KERN ABJ 220-4M, Germany). The overall fish weight in each tank was computed and used for the growth performance parameters calculations. Fish total length was measured by a ruler. Each fish was kept separately in a labeled plastic bag in refrigerator $\left(-4^{\circ} \mathrm{C}\right)$ till the biochemical analysis. Growth parameters were calculated using the following formulae:

Growth parameters:

Weight gain $(\mathrm{g})=\mathrm{W}_{\mathrm{f}}-\mathrm{W}_{\mathrm{i}}$

Weight gain $(\%)=\left(\mathrm{W}_{\mathrm{f}}-\mathrm{W}_{\mathrm{i}} / \mathrm{W}_{\mathrm{i}}\right) \times 100$

Specific growth rate $\left(\mathrm{SGR}, \%\right.$ day $\left.^{-1}\right)=\left(\ln \mathrm{W}_{\mathrm{f}}-\ln \mathrm{W}_{\mathrm{i}}\right) \times 100 /$ duration (days)

Fulton's condition factor $\left(\mathrm{K}, \mathrm{g} / \mathrm{cm}^{3}\right)=\left(\right.$ fish weight $(\mathrm{g}) /$ fish length $\left.{ }^{3}(\mathrm{~cm})^{3}\right) \times 100$

Feed utilization:

Feed conversion ratio $(\mathrm{FCR})=$ feed fed $(\mathrm{g}) /$ body weight gain $(\mathrm{g})$

\subsection{Homogenization and biochemical analyses:}

The whole fish obtained from the refrigerator were homogenized separately in $3 \mathrm{ml}$ of 0.8 $\%$ freshly prepared sucrose solution. Sucrose solution were added in two steps. In the first step, $2 \mathrm{ml}$ was added, while in the second step $1 \mathrm{ml}$ was added to wash the sample tube and the homogenizer (MPW-320, Poland) rod. The homogenization process continues till the sample become well homogenized and no solid parts were present. During homogenization process the samples were cooled in ice bath to prevent enzymes' degradation by the heat produced during homogenization. The homogenates were transferred to a $5 \mathrm{ml}$ labeled plastic tubes. Afterwards, they were centrifuged for 5-7 minutes at 5000 round per minute (rpm) till the supernatants became clear. The supernatants were transferred to a labeled $2 \mathrm{ml}$ eppendorf tubes. Then, they were stored in a freezer $\left(-2\right.$ to $\left.-8{ }^{\circ} \mathrm{C}\right)$ for a period not more than 2 to 4 weeks till measuring the biochemical 
parameters. The biochemical parameters were measured using UV-Visible spectrophotometer (Sunostik, SBA-700 PLUS) according to the following procedures:

1- AST and ALT activities: According to enzymatic degradation of NADH (nicotineamide adenine dinucleotide hydrogen), AST (E.C 2.6.1.1) and ALT (E.C 2.6.1.2) activities were measured photometrically (Schumann et al., 2002) using biosystems diagnostic kit (Barcelona, Spain), catalogue no M11531i-23. The detection limits were 1.1 U/L for AST and 1.6 U/L for ALT.

2- Reduced Glutathione (GSH): It was measured colorimetrically in the reaction of 5, 5 'dithiobis (2- nitrobenzioc acid) (DTNB) with glutathione (GSH) producing yellow color (Beutler et al., 1963). The resulted color was measured at $405 \mathrm{~nm}$. It was quantified using bio-diagonistic kit (Giza, Egypt). Catalog no. GR 2511.

3- Catalase (CAT) activity: It was measured colorimetrically using bio-diagonistic kit (Giza, Egypt), catalogue no CA 25 17. Catalase reacts with a known quantity of $\mathrm{H}_{2} \mathrm{O}_{2}$. The reaction was stopped after exactly 60 seconds with CAT inhibitor. In the presence of horseradish peroxidase (HRP), the remaining $\mathrm{H}_{2} \mathrm{O}_{2}$ reacts with 3,5-dichloro-2hydroxybenzene sulfonic acid (DHBS) and 4-aminophenazone (AAP) to form a chromophore with a color intensity inversely proportional to the amount of CAT in the original sample (Fossati et al., 1980; Aebi, 1984). The produced color was measured at $510 \mathrm{~nm}$.

4- Total protein: It was measured colorimetrically using diagnostic kit (Diamond, Cairo, Egypt). Proteins were reacted with copper salts in an alkaline medium to produce intensive violet-blue complex (Young, 2001). The intensity of the color produced was measured at $546 \mathrm{~nm}(530 \mathrm{~nm}-570 \mathrm{~nm})$ and proportional to the total protein concentration in the sample. The sensitivity is $1 \mathrm{~g} / \mathrm{dL}=0.07 \mathrm{~A}$, and accuracy include correlation coefficient $=0.9918$.

\section{Statistical analysis}

All data were presented as mean \pm S.E. Data analysis were carried out using one-way ANOVA (Duncan test) by IBM SPSS statistical program version 20 (Duncan, 1957)

\section{RESULTS}

\section{Confirmation of extracted chitin}

FT-IR spectra (Figure 1) illustrates the main functional groups which are present in chitin structure, that was agreed with Kaya et al. (2017). Scanning electron micrograph (Figure 2) illustrates chitin morphology and its arrangement, that coincided with De Andrade et al. (2012). XRD pattern (Figure 3) confirm the crystallinity of shrimp extracted chitin. The pattern is identical to the most publicized XRD patterns of chitin (Abdou et al., 2008; Arrouze et al., 2019). 


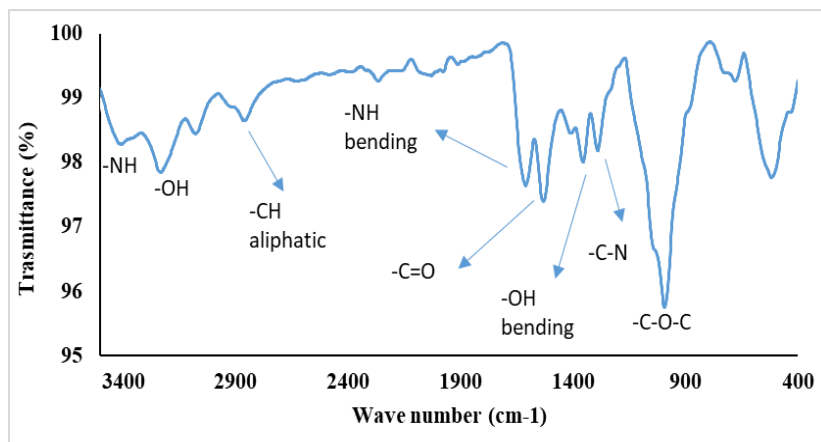

Figure 1. FT-IR spectra of chemically extracted chitin from shrimp solid wastes

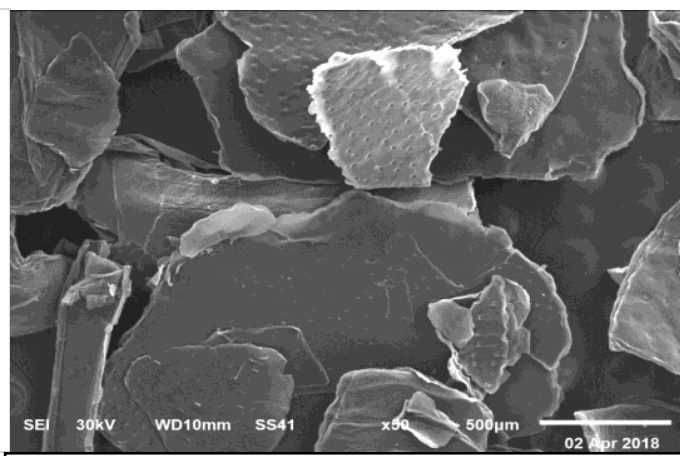

Figure 2. Scanning electron micrograph of chemically extracted chitin from shrimp solid wastes

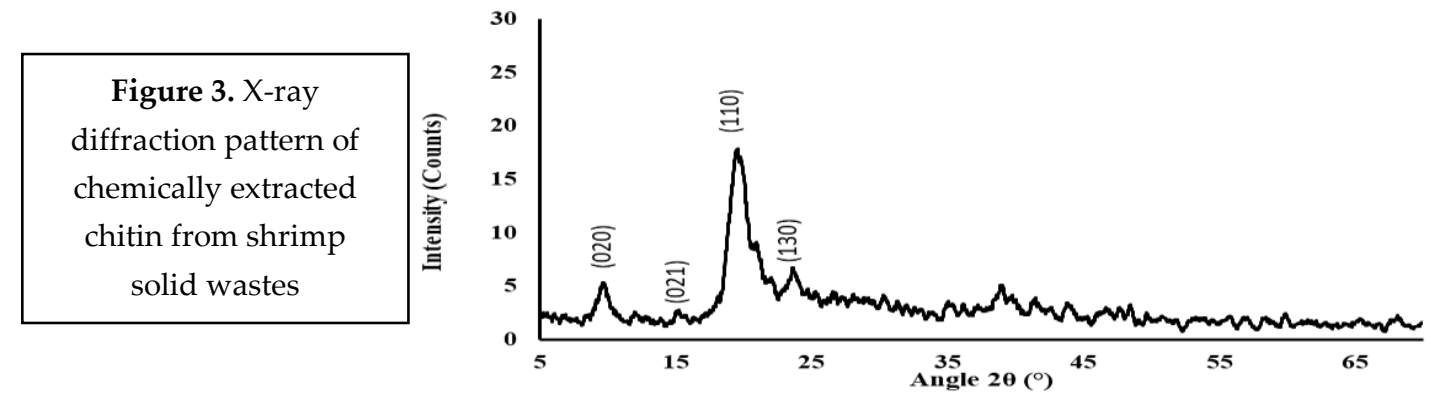

\section{Chitin yield}

Chitin yield from the shrimp exoskeleton waste extraction was computed based on the formula mentioned in materials and methods section. It was estimated in triplicate order, $30 \mathrm{~g}$ of the exoskeleton waste each time was processed for the chitin extraction. The average percentage of chitin yield was computed as the following:

Chitin yield $(\%)=((5.8+6+6.5 \mathrm{~g} / 3) / 30) \times 100=20.33 \% \pm 0.693($ mean \pm S.E. $)$

\section{Growth and feed utilization parameters}

Growth and feed utilization parameters are shown in Table (3). The highest final weight, weight gain, weight gain \%, SGR and the best FCR were obtained for G8 which fed the basal diet supplemented with $10 \%$ chitin + probiotic. The negative control group (G1) which fed the basal diet $(0 \%$ chitin) had the highest $\mathrm{K}$ value $(16.483 \pm 0.506 \mathrm{~g} / \mathrm{cm} 3)$. While, G8 recorded the second higher K value. Fingerlings of the same group (G8) had significant increase in their final weight, weight gain and weight gain $\%$ over those fed the basal diet with $0,2,10 \%$ chitin and $0 \%$ chitin + probiotic. Also, fingerlings of G8 were significantly better in SGR and FCR than $0 \%$ and $10 \%$ chitin groups. Nile tilapia fingerlings fed diet with $2 \%, 5 \%$ chitin alone and 2, 5\% chitin+probiotic had significant reduction in K values compared with the control group and G8 group. Similar trend was found in fingerlings fed basal diet with probiotic alone. During the experimentation the survival rate of the fish was high for all groups. It was $100 \%$ for all groups and $95 \%$ for both control and $5 \%$ chitin groups. 
Table 3. Effect of dietary chitin and chitin + probiotic on growth performance and feed utilization efficiency of $O$. niloticus fingerlings (\% as dry mass)

\begin{tabular}{|c|c|c|c|c|c|c|c|c|}
\hline & Basal diet & \multicolumn{3}{|c|}{ Chitin without probiotic } & Basal d.+ pro & \multicolumn{3}{|c|}{ Chitin with probiotic } \\
\hline groups & G1 & G2 & $\mathrm{G} 3$ & G4 & G5 & G6 & G7 & G8 \\
\hline parameters & $\begin{array}{l}\text { Negative } \\
\text { control }\end{array}$ & $\begin{array}{c}2 \% \\
\text { chitin }\end{array}$ & $\begin{array}{l}5 \% \\
\text { chitin }\end{array}$ & $\begin{array}{l}10 \% \\
\text { chitin }\end{array}$ & $\begin{array}{l}\text { Positive } \\
\text { control }\end{array}$ & $\begin{array}{l}2 \% \\
\text { chitin }\end{array}$ & $\begin{array}{l}5 \% \\
\text { chitin }\end{array}$ & $\begin{array}{l}10 \% \\
\text { chitin }\end{array}$ \\
\hline $\mathrm{Wi}$ & $\begin{array}{l}4.8725 \\
\pm 0.007\end{array}$ & $\begin{array}{c}4.863 \\
\pm 0.043\end{array}$ & $\begin{array}{c}4.793 \\
\pm 0.076\end{array}$ & $\begin{array}{c}4.848 \\
\pm 0.031\end{array}$ & $\begin{array}{c}4.819 \\
\pm 0.044\end{array}$ & $\begin{array}{c}4.758 \\
\pm 0.054\end{array}$ & $\begin{array}{c}4.898 \\
\pm 0.037\end{array}$ & $\begin{array}{c}4.773 \\
\pm 0.102\end{array}$ \\
\hline Wf & $\begin{array}{c}12.525^{\mathrm{ab}} \\
\pm 0.518\end{array}$ & $\begin{array}{c}13.104^{\mathrm{ab}} \\
\pm 1.566\end{array}$ & $\begin{array}{c}14.388^{\mathrm{abc}} \\
\pm 1.04\end{array}$ & $\begin{array}{c}11.638^{\mathrm{a}} \\
\pm 0.996\end{array}$ & $\begin{array}{c}13.018^{\mathrm{ab}} \\
\pm 1.291\end{array}$ & $\begin{array}{c}15.634^{\mathrm{bc}} \\
\pm 1.343\end{array}$ & $\begin{array}{c}14.167^{\mathrm{abc}} \\
\pm 0.407\end{array}$ & $\begin{array}{c}17.0^{\mathrm{c}} \\
\pm 0.184\end{array}$ \\
\hline $\mathrm{W}$ gain & $\begin{array}{l}7.653^{a b} \\
\pm 0.525\end{array}$ & $\begin{array}{l}8.241^{a b} \\
\pm 1.609\end{array}$ & $\begin{array}{c}9.595^{\mathrm{abc}} \\
\pm 0.963\end{array}$ & $\begin{array}{l}6.790^{\mathrm{a}} \\
\pm 1.027\end{array}$ & $\begin{array}{c}8.2^{a b} \\
\pm 1.247\end{array}$ & $\begin{array}{c}10.606^{\mathrm{bc}} \\
\pm 1.397\end{array}$ & $\begin{array}{c}9.269^{a b c} \\
\pm 0.444\end{array}$ & $\begin{array}{l}12.226^{\mathrm{c}} \\
\pm 0.081\end{array}$ \\
\hline $\mathrm{W}$ gain $(\%)$ & $\begin{array}{c}157.017^{\mathrm{ab}} \\
\pm 11.026\end{array}$ & $\begin{array}{c}169.758^{\mathrm{ab}} \\
\pm 34.597\end{array}$ & $\begin{array}{c}199.949^{\mathrm{abc}} \\
\pm 16.912\end{array}$ & $\begin{array}{c}140.226^{\mathrm{a}} \\
\pm 22.107\end{array}$ & $\begin{array}{c}169.952^{\text {ab }} \\
\pm 24.309\end{array}$ & $\begin{array}{l}223.27^{b c} \\
\pm 31.895\end{array}$ & $\begin{array}{c}189.33^{\mathrm{abc}} \\
\pm 10.505\end{array}$ & $\begin{array}{r}256.214^{\mathrm{c}} \\
\pm 3.794^{\circ}\end{array}$ \\
\hline SGR & $\begin{array}{l}1.209^{\mathrm{ab}} \\
\pm 0.055\end{array}$ & $\begin{array}{l}1.261^{\mathrm{abc}} \\
\pm 0.165\end{array}$ & $\begin{array}{c}1.406^{\mathrm{abc}} \\
\pm 0.072\end{array}$ & $\begin{array}{l}1.118^{\mathrm{a}} \\
\pm 0.118\end{array}$ & $\begin{array}{c}1.267^{\mathrm{abc}} \\
\pm 0.115\end{array}$ & $\begin{array}{l}1.497^{b c} \\
\pm 0.126\end{array}$ & $\begin{array}{l}1.361^{\mathrm{abc}} \\
\pm 0.046\end{array}$ & $\begin{array}{l}1.628^{c} \\
\pm 0.013\end{array}$ \\
\hline $\mathrm{K}$ & $\begin{array}{l}1.648^{\mathrm{c}} \\
\pm 0.050\end{array}$ & $\begin{array}{l}1.531^{a b} \\
\pm 0.004\end{array}$ & $\begin{array}{l}1.489^{\mathrm{a}} \\
\pm 0.034\end{array}$ & $\begin{array}{c}1.566^{\mathrm{abc}} \\
\pm 0.011\end{array}$ & $\begin{array}{l}1.487^{\mathrm{a}} \\
\pm 0.012\end{array}$ & $\begin{array}{l}1.524^{a b} \\
\pm 0.045\end{array}$ & $\begin{array}{l}1.524^{\mathrm{ab}} \\
\pm 0.017\end{array}$ & $\begin{array}{l}1.622^{b c} \\
\pm 0.002\end{array}$ \\
\hline FCR & $\begin{array}{l}3.168^{b c} \\
\pm 0.050\end{array}$ & $\begin{array}{l}3.129^{a b c} \\
\pm 0.386\end{array}$ & $\begin{array}{l}2.721^{\mathrm{ab}} \\
\pm 0.067\end{array}$ & $\begin{array}{c}3.603^{c} \\
\pm 0.3675\end{array}$ & $\begin{array}{c}3.145^{\mathrm{abc}} \\
\pm 0.268\end{array}$ & $\begin{array}{l}2.659^{a b} \\
\pm 0.180\end{array}$ & $\begin{array}{c}2.884^{a b c} \\
\pm 0.130\end{array}$ & $\begin{array}{l}2.344^{\mathrm{a}} \\
\pm 0.048\end{array}$ \\
\hline Survival (\%) & $95 \pm 0.5$ & 100 & $95 \pm 0.5$ & 100 & 100 & 100 & 100 & 100 \\
\hline
\end{tabular}

Wi: (mean initial weight), Wf: (mean final weight), W: (weight), SGR: (specific growth rate), K: (fulton condition factor), FCR: (feed conversion ratio). Means with different superscript letters in the same row are significantly different at $\mathrm{P} \leq$ 0.05. All data presented as mean \pm S.E.

\section{Biochemical parameters}

It is worthy to mention that the changes in both ALT and AST activities were not significant between all groups. The results of ALT showed that the control group which fed the basal diet (G1) had the lowest activity and the group (G6) which fed diet having $2 \%$ chitin with probiotic had the highest activity. AST results illustrated that the group fed $2 \%$ chitin diet (G2) recorded the lowest activity and the highest activity was noticed in the group fed $10 \%$ chitin with probiotic (G8).

The catalase (CAT) activity as an antioxidant biomarker was increased significantly in the group fed 5\% chitin with probiotic (G7) over all other groups. On the other hand, the group fed $10 \%$ chitin with probiotic (G8) had the lowest CAT activity that was non significantly varied from all tested groups except G7. While, the glutathione (GSH) content was increased significantly in the group fed the basal diet with probiotic (G5) and the group fed 5\% chitin with probiotic (G7) compared with the control group (G1). Also, the groups fed diets having $2 \%$ and $10 \%$ chitin with probiotic (G6 and G8, respectively) had significant increase in GSH content over the groups fed the basal diet (G1) and 5\% chitin (G3). It was prominent that all groups fed diets with probiotic had higher GSH content than groups fed diets devoid of probiotic. Only fingerlings of $2 \%$ and $10 \%$ chitin (G2 and G4) groups exhibited non- significant decrease in GSH (Table 4).

The total protein content was significantly increased in the group fed diet having $10 \%$ chitin (G4) over all other groups. Moreover, its content in the groups fed basal diet (G1), 2\% chitin (G2) and 5\% chitin (G3) was significantly increased over all groups fed diet containing probiotic whether having chitin or not (G5, G6, G7 and G8). Therefore, it was eminent that all groups fed 
diets devoid of probiotic had significant increase in the total protein content over the groups fed diets containing probiotic. In this context, the total protein content was significantly reduced in fish fingerlings fed the basal diet supplemented with probiotic only compared with those fed the basal diet.Therefore, and based on these data, it can be observed that the supplementation of probiotic was a causative factor for reducing the total protein content in the overall fish body (Table 4).

Table 4. Effect of dietary chitin and chitin supported with probiotic on biochemical parameters of $O$. niloticus fingerlings (\% as dry mass)

\begin{tabular}{|c|c|c|c|c|c|c|c|c|}
\hline \multirow[b]{2}{*}{ groups } & \multirow{2}{*}{$\begin{array}{c}\text { Basal diet } \\
\text { G1 }\end{array}$} & \multicolumn{3}{|c|}{ Chitin without probiotic } & \multirow{2}{*}{$\begin{array}{c}\begin{array}{c}\text { Basal d.+ } \\
\text { probiotic }\end{array} \\
\text { G5 }\end{array}$} & \multicolumn{3}{|c|}{ Chitin with probiotic } \\
\hline & & $\mathrm{G} 2$ & G3 & G4 & & G6 & G7 & G8 \\
\hline $\operatorname{ALT}(\mathrm{g} / \mathrm{L})$ & $\begin{array}{c}25.679^{\mathrm{a}} \\
\pm 2.19\end{array}$ & $\begin{array}{l}36.014^{\mathrm{a}} \\
\pm 9.526\end{array}$ & $\begin{array}{c}38.507^{\mathrm{a}} \\
\pm 14.396\end{array}$ & $\begin{array}{c}68.882^{\mathrm{a}} \\
\pm 16.839\end{array}$ & $\begin{array}{c}55.698^{a} \\
\pm 10.559\end{array}$ & $\begin{array}{c}72.142^{\mathrm{a}} \\
\pm 26.519\end{array}$ & $\begin{array}{c}32.796^{\mathrm{a}} \\
\pm 10.362\end{array}$ & $\begin{array}{c}39.232^{\mathrm{a}} \\
\pm 12.653\end{array}$ \\
\hline $\operatorname{AST}(g / L)$ & $\begin{array}{l}157.933^{\mathrm{a}} \\
\pm 44.944\end{array}$ & $\begin{array}{l}136.091^{\mathrm{a}} \\
\pm 40.430\end{array}$ & $\begin{array}{l}319.129^{\mathrm{a}} \\
\pm 60.363\end{array}$ & $\begin{array}{l}235.704^{\mathrm{a}} \\
\pm 69.606\end{array}$ & $\begin{array}{l}274.464^{\mathrm{a}} \\
\pm 77.446\end{array}$ & $\begin{array}{l}289.624^{\mathrm{a}} \\
\pm 45.732\end{array}$ & $\begin{array}{l}180.769^{\mathrm{a}} \\
\pm 52.198\end{array}$ & $\begin{array}{l}319.998^{\mathrm{a}} \\
\pm 79.092\end{array}$ \\
\hline $\begin{array}{l}\text { CAT } \\
(\mathrm{U} / \mathrm{L})\end{array}$ & $\begin{array}{c}60.941^{\mathrm{a}} \\
\pm 15.877\end{array}$ & $\begin{array}{c}84.004^{\mathrm{ab}} \\
\pm 8.425\end{array}$ & $\begin{array}{c}54.203^{\mathrm{a}} \\
\pm 4.51\end{array}$ & $\begin{array}{l}87.301^{\text {ab }} \\
\pm 19.664\end{array}$ & $\begin{array}{l}55.062^{\mathrm{a}} \\
\pm 6.844\end{array}$ & $\begin{array}{c}63.352^{\mathrm{ab}} \\
\pm 8.376\end{array}$ & $\begin{array}{l}101.313^{\mathrm{c}} \\
\pm 18.432\end{array}$ & $\begin{array}{l}53.795^{\mathrm{a}} \\
\pm 8.958\end{array}$ \\
\hline $\begin{array}{c}\text { GSH } \\
(\mathrm{mg} / \mathrm{dL})\end{array}$ & $\begin{array}{l}0.204^{\mathrm{a}} \\
\pm 0.057\end{array}$ & $\begin{array}{l}4.743^{\mathrm{abc}} \\
\pm 1.529\end{array}$ & $\begin{array}{l}2.625^{\mathrm{ab}} \\
\pm 1.218\end{array}$ & $\begin{array}{l}5.841^{\mathrm{abc}} \\
\pm 1.284\end{array}$ & $\begin{array}{l}8.084^{b c} \\
\pm 2.533\end{array}$ & $\begin{array}{l}9.977^{\mathrm{c}} \\
\pm 2.002\end{array}$ & $\begin{array}{l}8.365^{\mathrm{bc}} \\
\pm 1.268\end{array}$ & $\begin{array}{l}9.628^{\mathrm{c}} \\
\pm 3.242\end{array}$ \\
\hline $\mathrm{TP}(\mathrm{U} / \mathrm{ml})$ & $\begin{array}{l}5.974^{b} \\
\pm 1.366\end{array}$ & $\begin{array}{c}7.040^{b} \\
\pm 0.539\end{array}$ & $\begin{array}{l}5.429^{b} \\
\pm 0.592\end{array}$ & $\begin{array}{l}10.381^{\mathrm{c}} \\
\pm 1.006\end{array}$ & $\begin{array}{c}1.243^{\mathrm{a}} \\
\pm 0.088\end{array}$ & $\begin{array}{c}1.261^{\mathrm{a}} \\
\pm 0.151\end{array}$ & $\begin{array}{c}1.358^{\mathrm{a}} \\
\pm 0.461\end{array}$ & $\begin{array}{c}0.965^{\mathrm{a}} \\
\pm 0.037\end{array}$ \\
\hline
\end{tabular}

AST: (Aspartate aminotransferase), ALT: (Alanine aminotransferase), CAT: (Catalase), GSH: (Glutathione reduced), TP: (Total Protein). Means with different superscript letters in the same row are significantly different at at $\mathrm{P} \leq 0.05$. All data presented as mean \pm S.E.

\section{DISCUSSION}

Growth performance parameters are used extensively for evaluating the different diets as well as different supplements on fish (Aziza et al., 2020; Naiel $\boldsymbol{e t}$ al., 2020). In the present study, the basal diet supplemented with chitin (2\% and 5\%) induces non-significant increase in growth performance parameters compared with the control. Worthy to mention that, the highest used chitin concentration (10\%) evoked growth performance like those of the control. This contrasts with those reported earlier. It has been found that chitin supplementation induces faster growth and better health for different fish species such as Yellowtail, sea bream and Japanese eel (Kono et al., 1987).

Chitinolytic enzymes are distributed in different parts of the digestive tract of fishes where they have high activities. Similarly, they have different functions among different fish species (Molinari et al., 2007; Fines and Holt, 2010; Ikeda et al., 2017; Baehaki et al., 2018). However, chitinolytic enzymes functions are variable and species-specific, the major function is the breakdown of chitin (Lindsay, 1984). Chitinase activity has been measured in stomach, intestine and 
serum of Nile tilapia (O. niloticus). Its function in the serum may be to play a defensive role against chitinous pathogens (Molinari et al., 2007). It is well known that, larval stages of most fishes depend mainly on crustacean zooplankton for feeding (Danulat, 1987). The chitinase activities are unequally distributed in the alimentary tract (Matsumiya and Mochizuki, 1996). Most teleost fishes have several chitinases in their stomachs (Ikeda et al., 2017). These enzymes primarily function in the break-down of chitinous materials presented with their diets (Gutowska et al., 2004; Ikeda et al., 2017).

The probiotics use in aquaculture help to improve fish digestibility and therefore improve feed utilization (Opiyo et al., 2019; Tan $\boldsymbol{e t}$ al., 2019). It is used experimentally as an aquafeed supplement for different fish species (Banerjee and Ray, 2017; Tachibana et al., 2020; Xia et al., 2020). Its use in aquaculture has been reported to be useful as they have several benefits including growth and immune enhancement, inhibit pathogenic microorganisms, supporting health and improving water quality in fishes and especially tilapia (Dawood et al., 2020). Numerous studies have been conducted to estimate the effect of different probiotics on Nile tilapia. They ascertain that probiotics effectively improve metabolic activity, immune response, feed digestibility, water quality and growth performance (Adeoye et al., 2016; Opiyo et al., 2019; Tan et al., 2019; Dawood et al., 2020; Tachibana et al., 2020).

The reported data in the present study declare that the growth performance parameters of tilapia fish fed the basal diet supplemented with the , those fed the basal diet supplemented with 10 $\%$ chitin. Meanwhile, the diets supplemented with paired chitin and the probiotic promoted faster growth rate presented as weight gain, final weight, SGR, and better feed utilization presented as significant lower FCR values. It is noteworthy mentioning that, the highest tested dietary chitin level $(10 \%)$ alone promoted a non-significant reduction in the tested growth performance and feed utilization parameters. The obtained data in this study declared that chitin supplementation alone didn't induce significant increase of Nile tilapia growth. These results for Nile tilapia are contradictory to those reported previously for different fish species fed chitin supplemented diet (Kono et al., 1987). Meanwhile, data reported previously for hybrid tilapia fed chitin supplemented diet declare significant reduction of growth parameters (Shiau and Yu, 1999), and this was contradictory to the present results for tilapia fed diet supplemented with chitin. Similarly, the Procambarus clarkii by-product meal induces general reduction of the growth performance of Nile tilapia with significant value for $75 \%$ and $100 \%$ replacement with fish meal (Hady et al., 2019). However, Nile tilapia have chitinase activity in its stomach, intestine and serum (Molinari et al., 2007). However, the addition of the probiotic with basal diet $+10 \%$ chitin level promoted the highest growth performance parameters and the best FCR value (the lowest). This indicates the importance of addition of a probiotic along with chitin for improving its digestibility. To the best of our knowledge, this is the first attempt to improve chitin digestibility using probiotic supplementation.

Enzymes activity measurement are among the main biochemical parameters that can evaluate the effect of fish diet supplements on fish metabolic activity (Fadl $\boldsymbol{e t}$ al., 2020; Xu et al., 2020). In the present study ALT and AST activities in all groups (except AST activity of G2) were not significantly increased, over the control group. This indicates that chitin as a feed supplement doesn't cause any liver or tissue damages. These results are consistent with the fact that enzyme synthesis follows the physiological feedback mechanism. Thus, AST and ALT activities are changed significantly in the case of the presence of stress factors that may cause tissue and liver damage (Al-Khashali and Al-Shawi, 2013; Ranjan et al., 2020; Sakyi et al., 2020; Zahran et 
al., 2020). These results are consistent with the finding that was reported for the deacetylated derivative of chitin (chitosan) supplemented diet don't affect AST and ALT activities of Nile tilapia (Fadl et al., 2020). Also, Hady et al. (2019) found that the Procambarus clarkia (freshwater crayfish) by-product meal did not induce any alterations in the liver and gills of $O$. niloticus.

Generally, CAT activity was non-significantly fluctuated in tilapia fed diet with chitin and/or chitin+probiotic. It is worthy to mention that, fish fed $5 \%$ chitin with probiotic has a significant increase in CAT activity over all other groups. This reflects enhanced antioxidant profile for tilapia with more capacity for scavenging reactive oxygen species (ROS). Moving to GSH, its content was raised non-significantly due to feeding on diet supplemented with chitin. Also, its content in all fish groups supported with diets with the probiotic were significantly increased over fish fed the basal diet. This also indicates the increase of antioxidant capacity of Nile tilapia. Different studies ascertain that chitin enhances immune response of different fish species such as gilthead seabream, Sparus aurata, (Gopalakannan and Arul, 2006), kelp grouper, Epinephelus bruneus, (Harikrishnan et al., 2012) and mrigal carp, Cirrhinus mrigala, (Shanthi Mari et al., 2014). It has been approved that diets supplemented with hydrolyzed shrimp shell chitin change autochthonous (indigenous) gut bacteria and improve intestinal health resistance to infection of hybrid tilapia (Qin et al., 2014). Also, our results are supported with the assumption that chitin and its derivatives possibly act as prebiotic which can enhance gut epithelial barrier function, beneficial gut microbiome and produce intermediate metabolites (as short-chain fatty acids) which assist in immune system balancing (Nawaz et al., 2018).

In the present study, the total protein content in whole Nile tilapia body was significantly reduced due to the addition of the probiotic to the basal diet. It's well known that, chitin and cellulose are categorized as non-digestible fibers (Krogdahl $\boldsymbol{e t}$ al., 2005). Different studies suggest that fish preys contain chitin which may protect the prey exoskeleton against digestive enzymes of the fish. So, chitin regarded as a foreign material when ingested with fish feeds (Gutowska $\boldsymbol{e t}$ al., 2004; Lindsay, 1984). Other studies suggest that chitinases function as defensive enzymes against chitinous materials. High chitinase activity has been measured in serum of Nile tilapia $(O$. niloticus) which may have defensive function promoted by chitinous materials (Molinari et al., 2007). The findings of the present study ascertain that the groups fed diets devoid of the probiotic have high total protein content which play a role in immune defense. Therefore, in this study, the overall protein metabolic pathways may be directed to synthesize defensive proteins related to chitin and/or cellulose (in basal diet) rather than fish muscle growth. On the other hand, it is well known that probiotics play a significant role in the fermentation of non-digestible fibers which are regarded as prebiotic such as chitin (Nawaz et al., 2018; Lopez-Santamarina et al., 2020) . The addition of the probiotic act to ferment the chitin to useful non-foreign products. Thus, the overall protein metabolic pathways may be directed to the muscle growth rather than the synthesis of defensive proteins. This hypothesis is consistent with the reported data of growth parameters obtained in the present study.

\section{CONCLUSION}

The current study ascertains that the addition of shrimp waste chemically extracted chitin with probiotic to the basal diet enhances the growth parameters and the antioxidant activity of Nile tilapia fry $(O$. niloticus). Furthermore, chitin in the diet as a prebiotic when added to the diet supplemented with probiotic, it has a synergistic effect and therefore they (chitin and probiotic) act 
as a synbiotic. Therefore, and based on the presented data, it is worthy to recommend the use of chitin as an aquafeed additive in aquaculture for sustainability.

\section{REFERENCES}

Abdou, E. S.; Nagy, K. S. A. and Elsabee, M. Z. (2008). Extraction and characterization of chitin and chitosan from local sources. Bioresource Technology, 99 (5): 1359-1367. https://doi.org/10.1016/j.biortech.2007.01.051

Adeoye, A. A.; Yomla, R.; Jaramillo-Torres, A.; Rodiles, A.; Merrifield, D. L. and Davies, S. J. (2016). Combined effects of exogenous enzymes and probiotic on Nile tilapia (Oreochromis niloticus) growth, intestinal morphology and microbiome. Aquaculture, 463: 61-70. https://doi.org/10.1016/j.aquaculture.2016.05.028

Aebi, H. (1984). Catalase in vitro. Methods in Enzymology, 105: 121-126. https://doi.org/10.1016/s0076-6879(84)05016-3

Agboh, O. C. and Qin, Y. (1997). Chitin and chitosan fibers. Polymers for Advanced Technologies, $\quad 8 \quad$ (6): $355-365 . \quad$ https://doi.org/10.1002/(SICI)10991581(199706)8:6<355::AID-PAT651>3.0.CO;2-T

Ahmad, S. I.; Ahmad, R.; Khan, M. S.; Kant, R.; Shahid, S.; Gautam, L.; Hasan, G. M. and Hassan, M. I. (2020). Chitin and its derivatives: Structural properties and biomedical applications. International Journal of Biological Macromolecules, 164: 526-539. https://doi.org/10.1016/j.ijbiomac.2020.07.098

Ahmed, N. and Thompson, S. (2019). The blue dimensions of aquaculture: A global synthesis. Science of the Total Environment, 652: 851-861. https://doi.org/10.1016/j.scitotenv.2018.10.163

Al-Khashali, M. S. and Al-Shawi, S. A. S. (2013). Effect of salt stress on ALT and AST enzymes activity and cortisol level in adults of Carassius auratus. Pakistan Journal of Nutrition, 12 (1): 97-100. https://doi.org/10.3923/pjn.2013.97.100

Arrouze, F.; Desbrieres, J.; Rhazi, M.; Essahli, M. and Tolaimate, A. (2019). Valorization of chitins extracted from North Morocco shrimps: Comparison of chitin reactivity and characteristics. Journal of Applied Polymer Science, 136 (30): 1-10. https://doi.org/10.1002/app.47804

Aziza, A.; Mahmoud, R.; Zahran, E. and Gadalla, H. (2020). Dietary supplementation of guanidinoacetic acid improves growth, biochemical parameters, antioxidant capacity and cytokine responses in Nile tilapia (Oreochromis niloticus). Fish and Shellfish Immunology, 97: 367-374. https://doi.org/10.1016/j.fsi.2019.12.052

Baehaki, A.; Lestari, S. D.; Wahidman, Y. and Gofar, N. (2018). Characteristics of chitinase isolated from different part of snakehead fish (Channa striata) digestive tract. IOP Conference Series: Earth and Environmental Science, 102 (1): 6-10. https://doi.org/10.1088/1755-1315/102/1/012057

Banerjee, G. and Ray, A. K. (2017). The advancement of probiotics research and its application in fish farming industries. Research in Veterinary Science, 115: 66-77. https://doi.org/10.1016/j.rvsc.2017.01.016

Barikani, M.; Oliaei, E.; Seddiqi, H. and Honarkar, H. (2014). Preparation and application of chitin and its derivatives: A review. Iranian Polymer Journal (English Edition), 23 (4): 307-326. https://doi.org/10.1007/s13726-014-0225-Z

Beutler, E.; Duron, O. and Kelly, B. M. (1963). Improved method for the determination of blood 
glutathione. The Journal of Laboratory and Clinical Medicine, 61: 882-888.

Borić, M.; Vicente, F. A.; Jurković, D. L.; Novak, U. and Likozar, B. (2020). Chitin isolation from crustacean waste using a hybrid demineralization/DBD plasma process. Carbohydrate Polymers, 246: 1-8 . https://doi.org/10.1016/j.carbpol.2020.116648

Croisier, F. and Jérôme, C. (2013). Chitosan-based biomaterials for tissue engineering. European Polymer Journal, 49 (4): 780-792. https://doi.org/10.1016/j.eurpolymj.2012.12.009

Danulat, E. (1987). Digestibility of chitin in cod, Gadus morhua, in vivo. Helgoländer Meeresuntersuchungen (Helgoland Marine Research), 41 (4): 425-436. https://doi.org/10.1007/BF02365402

Dawood, M. A. O.; Eweedah, N. M.; Moustafa, E. M. and Farahat, E. M. (2020). Probiotic effects of Aspergillus oryzae on the oxidative status, heat shock protein, and immune related gene expression of Nile tilapia (Oreochromis niloticus) under hypoxia challenge. Aquaculture, 520: 1-9. https://doi.org/10.1016/j.aquaculture.2019.734669

De Andrade, S. M. B.; Ladchumananandasivam, R.; da Rocha, B. G.; Belarmino, D. D. and Galvão, A. O. (2012). The Use of Exoskeletons of Shrimp (Litopenaeus vanammei) and Crab (Ucides cordatus) for the Extraction of Chitosan and Production of Nanomembrane. Materials Sciences and Applications, 3 (7): 495-508. https://doi.org/10.4236/msa.2012.37070

Deng, J. J.; Mao, H. H.; Fang, W.; Li, Z. Q.; Shi, D.; Li, Z. W.; Zhou, T. and Luo, X. C. (2020). Enzymatic conversion and recovery of protein, chitin, and astaxanthin from shrimp shell $\begin{array}{llll}\text { waste. Journal of } & \text { Cleaner }\end{array}$ https://doi.org/10.1016/j.jclepro.2020.122655

Duncan, B. D. (1957). Multiple range tests for correlated and heteroscedastic means. Biometrics, 13 (2): 164-176. https://doi.org/10.2307/2527799

Elieh-Ali-Komi, D. and Hamblin, M. R. (2016). Chitin and Chitosan: Production and Application of Versatile Biomedical Nanomaterials. International Journal of Advanced Research, 4 (3): 411-427.

http://www.ncbi.nlm.nih.gov/pubmed/27819009\%0Ahttp://www.pubmedcentral.nih.gov/artic lerender.fcgi?artid=PMC5094803

El-Sayed, A.-F.M. (2006). Tilapia culture, first edition. CABI international publisher, Oxfordshire, Wallingford, UK. P1.

Fadl, S. E.; El-Gammal, G. A.; Abdo, W. S.; Barakat, M.; Sakr, O. A.; Nassef, E.; Gad, D. M. and El-Sheshtawy, H. S. (2020). Evaluation of dietary chitosan effects on growth performance, immunity, body composition and histopathology of Nile tilapia (Oreochromis niloticus) as well as the resistance to Streptococcus agalactiae infection. Aquaculture Research, 51 (3): 1120-1132. https://doi.org/10.1111/are.14458

FAO. (2020). The State of World Fisheries and Aquaculture. sustainability in action.Rome. p2. https://doi.org/10.4060/ca9229en

Fines, B. C. and Holt, G. J. (2010). Chitinase and apparent digestibility of chitin in the digestive tract of juvenile cobia, Rachycentron canadum. Aquaculture, 303: 34-39. https://doi.org/10.1016/j.aquaculture.2010.03.010

Fossati, P.; Prencipe, L. and Berti, G. (1980). Use of 3,5-dichloro-2-hydroxybenzenesulfonic acid/4-aminophenazone chromogenic system in direct enzymic assay of uric acid in serum and urine. Clinical Chemistry, 26 (2): 227-231.

Gephart, J. A.; Golden, C. D.; Asche, F.; Belton, B.; Brugere, C.; Froehlich, H. E.; Fry, J. P.; Halpern, B. S.; Hicks, C. C.; Jones, R. C.; Klinger, D. H.; Little, D. C.; McCauley, D. J.; Thilsted, S. H.; Troell, M. and Allison, E. H. (2020). Scenarios for Global Aquaculture and Its 
Role in Human Nutrition. Reviews in Fisheries Science and Aquaculture, 1-17. https://doi.org/10.1080/23308249.2020.1782342

Gopalakannan, A. and Arul, V. (2006). Immunomodulatory effects of dietary intake of chitin, chitosan and levamisole on the immune system of Cyprinus carpio and control of Aeromonas hydrophila infection in ponds. Aquaculture, 255 (1-4): 179-187. https://doi.org/10.1016/j.aquaculture.2006.01.012

Gutowska, M. A.; Drazen, J. C. and Robison, B. H. (2004). Digestive chitinolytic activity in marine fishes of Monterey Bay, California. Comparative Biochemistry and Physiology, 139 (3): 351-358. https://doi.org/10.1016/j.cbpb.2004.09.020

Habashy, W. S.; Milfort, M. C.; Rekaya, R. and Aggrey, S. E. (2019). Cellular antioxidant enzyme activity and biomarkers for oxidative stress are affected by heat stress. International Journal of Biometeorology, 63 (12): 1569-1584. https://doi.org/10.1007/s00484-019-01769-z

Hady, F. K. A.; Deeb, R.; Saad, A. and Rahman, F. (2019). Effect of partial or total replacement of fish meal with Procambarus clarkii by-product meal in Oreochromis niloticus diets. The Egyptian journal of experimental Biology (Zoology), 15 (2): 277-288. https://doi.org/10.5455/egysebz.20191209062931

Harikrishnan, R.; Kim, J. S.; Balasundaram, C. and Heo, M. S. (2012). Dietary supplementation with chitin and chitosan on haematology and innate immune response in Epinephelus bruneus against Philasterides dicentrarchi. Experimental Parasitology, 131 (1): 116-124. https://doi.org/10.1016/j.exppara.2012.03.020

Ikeda, M.; Kakizaki, H. and Matsumiya, M. (2017). Biochemistry of fish stomach chitinase. International Journal of Biological Macromolecules, 104: 1672-1681. https://doi.org/10.1016/i.ijbiomac.2017.03.118

Kaya, M.; Mujtaba, M.; Ehrlich, H.; Salaberria, A. M.; Baran, T.; Amemiya, C. T.; Galli, R.; Akyuz, L.; Sargin, I. and Labidi, J. (2017). On chemistry of $\gamma$-chitin. Carbohydrate Polymers, 176: 177-186. https://doi.org/10.1016/j.carbpol.2017.08.076

Kobayashi, A.; Suzuki, Y. and Sugai, S. (2020). Specificity of transaminase activities in the prediction of drug-induced hepatotoxicity. Journal of Toxicological Sciences, 45 (9): 515537. https://doi.org/10.2131/jts.45.515

Kono, M.; Shimizu, C. and Matsui, T. (1987). Effect of Chitin, Chitosan, and Cellulose as Diet Supplements on the Growth of Cultured Fish. Nippon Suisan Gakkaishi, 53 (1): 125-129. https://doi.org/10.2331/suisan.53.125

Krogdahl, Å; Hemre, G. I. and Mommsen, T. P. (2005). Carbohydrates in fish nutrition: Digestion and absorption in postlarval stages. Aquaculture Nutrition, 11 (2): 103-122. https://doi.org/10.1111/j.1365-2095.2004.00327.x

Kumar, A.; Kumar, D.; George, N.; Sharma, P. and Gupta, N. (2018). A process for complete biodegradation of shrimp waste by a novel marine isolate Paenibacillus sp. AD with simultaneous production of chitinase and chitin oligosaccharides. International Journal of Biological Macromolecules, 109: 263-272. https://doi.org/10.1016/j.ijbiomac.2017.12.024

Lindsay, G. J. H. (1984). Adsorption of rainbow trout (Salmo gairdneri) gastric lysozymes and chitinase by cellulose and chitin. Aquaculture, 42 (3-4): 241-246. https://doi.org/10.1016/0044-8486(84)90104-2

Lopez-Santamarina, A.; Mondragon, A. del C.; Lamas, A.; Miranda, J. M.; Franco, C. M. and Cepeda, A. (2020). Animal-origin prebiotics based on chitin: An alternative for the future? a critical review. Foods, 9 (6): 1-20. https://doi.org/10.3390/foods9060782

Ma, X.; Gözaydın, G.; Yang, H.; Ning, W.; Han, X.; Poon, N. Y.; Liang, H.; Yan, N. and Zhou, 
K. (2020). Upcycling chitin-containing waste into organonitrogen chemicals via an integrated process. Proceedings of the National Academy of Sciences of the United States of America, 117 (14): 7719-7728. https://doi.org/10.1073/pnas.1919862117

Matsumiya, M. and Mochizuki, A. (1996). Distribution of Chitinase and $\beta-\mathrm{N}$ Acetylhexosaminidase in the Organs of Several Fishes. Fisheries Science, 62 (1): 150-151. https://doi.org/10.2331/fishsci.64.166

Molinari, L. M.; Pedroso, R. B.; Scoaris, D. de O.; Ueda-Nakamura, T.; Nakamura, C. V. and Dias Filho, B. P. (2007). Identification and partial characterisation of a chitinase from Nile tilapia, Oreochromis niloticus. Comparative Biochemistry and Physiology - B Biochemistry and Molecular Biology, 146 (1): 81-87. https://doi.org/10.1016/j.cbpb.2006.09.004

Naiel, M. A. E.; Ismael, N. E. M.; Negm, S. S.; Ayyat, M. S. and Al-Sagheer, A. A. (2020). Rosemary leaf powder-supplemented diet enhances performance, antioxidant properties, immune status, and resistance against bacterial diseases in Nile Tilapia (Oreochromis niloticus). Aquaculture, 526: 1-8 . https://doi.org/10.1016/j.aquaculture.2020.735370

Nawaz, A.; Bakhsh javaid, A.; Irshad, S.; Hoseinifar, S. H. and Xiong, H. (2018). The functionality of prebiotics as immunostimulant: Evidences from trials on terrestrial and aquatic animals. Fish and Shellfish Immunology, 76: 272-278. https://doi.org/10.1016/j.fsi.2018.03.004

Nölle, N.; Genschick, S.; Schwadorf, K.; Hrenn, H.; Brandner, S. and Biesalski, H. K. (2020). Fish as a source of (micro)nutrients to combat hidden hunger in Zambia. Food Security, 12 (6): 1385-1406. https://doi.org/10.1007/s12571-020-01060-9

Opiyo, M. A.; Jumbe, J.; Ngugi, C. C. and Charo-Karisa, H. (2019). Different levels of probiotics affect growth, survival and body composition of Nile tilapia (Oreochromis niloticus) cultured in low input ponds. Scientific African, 4: e00103. https://doi.org/10.1016/j.sciaf.2019.e00103

Prabu, E.; Rajagopalsamy, C. B. T.; Ahilan, B.; Jeevagan, I. J. M. A. and Renuhadevi, M. (2019). Tilapia - An Excellent Candidate Species for World Aquaculture: A Review. Annual Research and Review in Biology, 31 (3): 1-14. https://doi.org/10.9734/arrb/2019/v31i330052

Qin, C.; Zhang, Y.; Liu, W.; Xu, L.; Yang, Y. and Zhou, Z. (2014). Effects of chitooligosaccharides supplementation on growth performance, intestinal cytokine expression, autochthonous gut bacteria and disease resistance in hybrid tilapia Oreochromis niloticus q $\times$ Oreochromis aureus $\hat{\sigma}$. Fish and Shellfish Immunology, 40 (1): 267-274. https://doi.org/10.1016/j.fsi.2014.07.010

Ranjan, A.; Srivastava, P. P.; Jain, K. K. and Muralidhar, P. A. (2020). Comparative evaluation of metabolic enzymes activities in different tissues of striped catfish, Pangasianodon hypophthalmus (Sauvage, 1878) fingerlings reared at ambient and higher temperature. Iranian Journal of Fisheries Sciences, 19 (2): 893-903. https://doi.org/10.22092/ijfs.2018.119831

Ring $\varnothing$, E.; Zhou, Z.; Olsen, R. E. and Song, S. K. (2012). Use of chitin and krill in aquaculture the effect on gut microbiota and the immune system: A review. Aquaculture Nutrition, 18 (2): 117-131. https://doi.org/10.1111/j.1365-2095.2011.00919.x

Sakyi, M. E.; Cai, J.; Tang, J.; Abarike, E. D.; Xia, L.; Li, P.; Kuebutornye, F. K. A.; Zou, Z.; Liang, Z. and Jian, J. (2020). Effects of starvation and subsequent re-feeding on intestinal microbiota, and metabolic responses in Nile tilapia, Oreochromis niloticus. Aquaculture Reports, 17 (1): 100370. https://doi.org/10.1016/j.aqrep.2020.100370

Schumann, G.; Bonora, R.; Ceriotti, F.; Férard, G.; Ferrero, C. A.; Franck, P. F. H.; Gella, F. J.; Hoelzel, W.; Jørgensen, P. J.; Kanno, T.; Kessner, A.; Klauke, R.; Kristiansen, N.; Lessinger, J.-M.; Linsinger, T. P. J.; Misaki, H.; Panteghini, M.; Pauwels, J.; Schiele, F. and Schimmel, 
H. G. (2002). IFCC primary reference procedures for the measurement of catalytic activity concentrations of enzymes at 37 degrees C. International Federation of Clinical Chemistry and Laboratory Medicine. Part 4. Reference procedure for the measurement of catalytic AST. Clinical Chemistry and Laboratory Medicine, 40 (7): 718-724. https://doi.org/10.1515/CCLM.2002.124

Sewaka, M.; Trullas, C.; Chotiko, A.; Rodkhum, C.; Chansue, N.; Boonanuntanasarn, S. and Pirarat, N. (2019). Efficacy of synbiotic Jerusalem artichoke and Lactobacillus rhamnosus GG-supplemented diets on growth performance, serum biochemical parameters, intestinal morphology, immune parameters and protection against Aeromonas veronii in juvenile red tilapia (Oreochromis ssp). Fish and Shellfish Immunology, 86: 260-268. https://doi.org/10.1016/j.fsi.2018.11.026

Shahidi, F. and Synowiecki, J. (1991). Isolation and Characterization of Nutrients and ValueAdded Products from Snow Crab (Chinoecetes Opilio) and Shrimp (Pandalus Borealis) Processing Discards. Journal of Agricultural and Food Chemistry, 39 (8): 1527-1532. https://doi.org/10.1021/jf00008a032

Shanthi Mari, L. S.; Jagruthi, C.; Anbazahan, S. M.,; Yogeshwari, G.; Thirumurugan, R.; Arockiaraj, J.; Mariappan, P.; Balasundaram, C. and Harikrishnan, R. (2014). Protective effect of chitin and chitosan enriched diets on immunity and disease resistance in Cirrhina mrigala against Aphanomyces invadans. Fish and Shellfish Immunology, 39 (2): 378-385. https://doi.org/10.1016/j.fsi.2014.05.027

Shiau, S. Y. and Yu, Y. P. (1999). Dietary supplementation of chitin and chitosan depresses growth in tilapia, Oreochromis niloticus X O. aureus. Aquaculture, 179 (1-4): 439-446. https://doi.org/10.1016/S0044-8486(99)00177-5

Silva, D. C.; Serrano, L.; Oliveira, T. M. A.; Mansano, A. S. ; Almeida, E. A. and Vieira, E. M. (2018). Effects of parabens on antioxidant system and oxidative damages in Nile tilapia (Oreochromis niloticus). Ecotoxicology and Environmental Safety, 162 : 85-91. https://doi.org/10.1016/j.ecoenv.2018.06.076

Stead, S. M. (2019). Using systems thinking and open innovation to strengthen aquaculture policy for the United Nations Sustainable Development Goals. Journal of Fish Biology, 94 (6): $837-$ 844. https://doi.org/10.1111/jfb.13970

Tachibana, L.; Telli, G. S.; de Carla Dias, D.; Gonçalves, G. S.; Ishikawa, C. M.; Cavalcante, R. B.; Natori, M. M.; Hamed, S. B. and Ranzani-Paiva, M. J. T. (2020). Effect of feeding strategy of probiotic Enterococcus faecium on growth performance, hematologic, biochemical parameters and non-specific immune response of Nile tilapia. Aquaculture Reports, 16: 100277. https://doi.org/10.1016/j.aqrep.2020.100277

Tan, H. Y.; Chen, S. W. and Hu, S. Y. (2019). Improvements in the growth performance, immunity, disease resistance, and gut microbiota by the probiotic Rummeliibacillus stabekisii in Nile tilapia (Oreochromis niloticus). Fish and Shellfish Immunology, 92: 265-275. https://doi.org/10.1016/j.fsi.2019.06.027

Tidwell, J. H. and Allan, G. L. (2001). Fish as food: aquaculture's contribution. EMBO Reports, 2 (11): 958-963. https://doi.org/10.1093/embo-reports/kve236

Wang, M. and Lu, M. (2016). Tilapia polyculture: a global review. Aquaculture Research, 47 (8): 2363-2374. https://doi.org/10.1111/are.12708

Xia, Y.; Wang, M.; Gao, F.; Lu, M. and Chen, G. (2020). Effects of dietary probiotic supplementation on the growth, gut health and disease resistance of juvenile Nile tilapia (Oreochromis niloticus). Animal Nutrition, 6 (1): 69-79. 
https://doi.org/10.1016/j.aninu.2019.07.002

Xu, Y.; Zheng, Y.; Li, W.; Liu, Y. and Ding, Z. (2020). Gene expression , antioxidation and growth were considerably promoted by feeding dietary vitamin $\mathrm{E}$ and alanyl-glutamine dipeptide supplementation in juvenile tilapia in cold freshwater. Aquaculturee nutrition, 26 (6): 2159-2168. https://doi.org/10.1111/anu.13154

Younes, I. and Rinaudo, M. (2015). Chitin and chitosan preparation from marine sources. Structure, properties and applications. Marine Drugs, 13 (3): 1133-1174. https://doi.org/10.3390/md13031133

Young, D. S. (2001) Effects of Drugs on Clinical Laboratory Tests. 5th ed. Volume 1 and 2. Washington, DC: The American Assocation for Clinical Chemistry Press.

Zahran, E.; Abdelhamid, F.; Aboelfadl, E. and El-Matbouli, M. (2020). Biomarker responses of Nile tilapia towards wastewater effluents exposure. Aquaculture Research, 2020: 1-13. https://doi.org/10.1111/are.14992

Zhu, K.; Shi, S.; Cao, Y.; Lu, A.; Hu, J. and Zhang, L. (2019). Robust chitin films with good biocompatibility and breathable properties. Carbohydrate Polymers, 212: 361-367. https://doi.org/10.1016/j.carbpol.2019.02.054

\section{تأثير الكايتين المستخرج من بقايا الجمبري على معدلات النمو و بعض التغيرات البيوكيميائية في سمكة البلطي النيلي صبري الصبرفي، نصرالله عبدالحميد، هاني عبدالسلام، علي دكروني

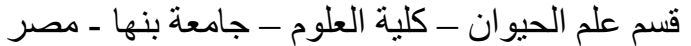

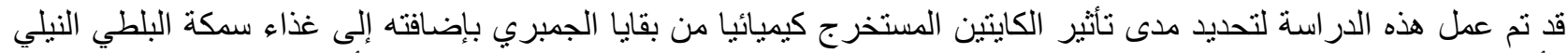

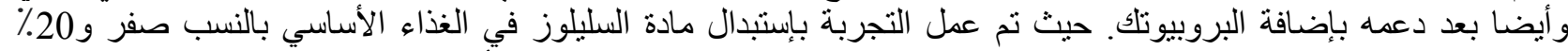

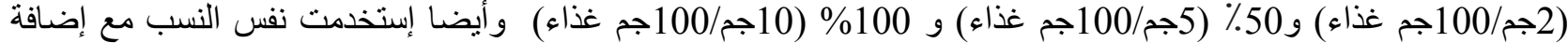

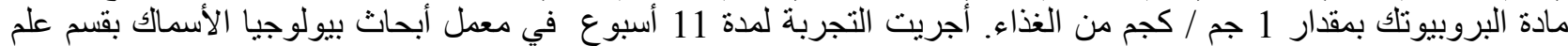

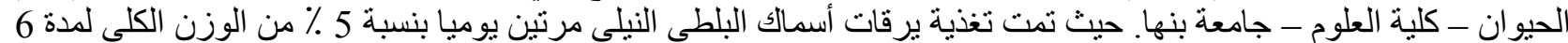

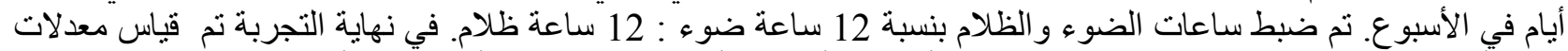

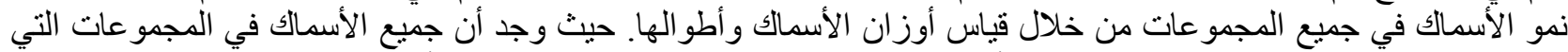

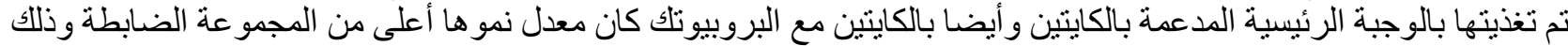

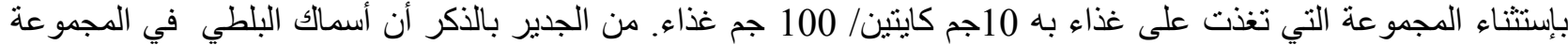

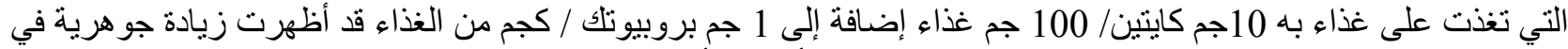

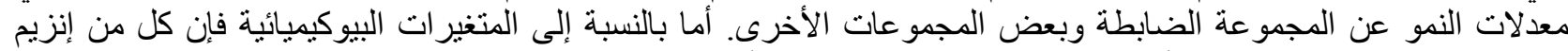

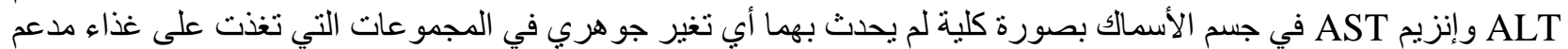

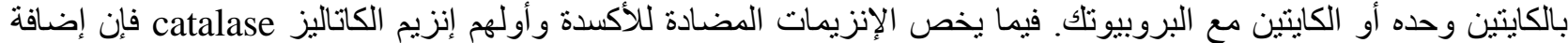

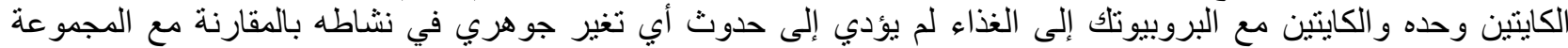

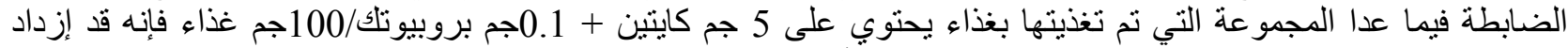

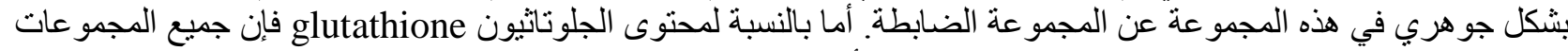

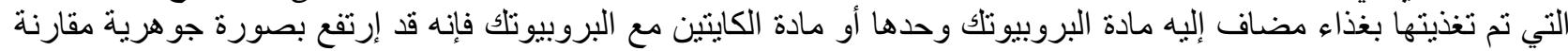

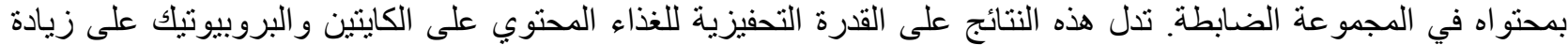

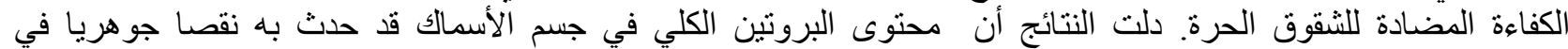

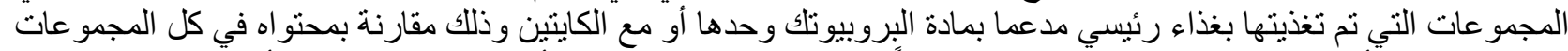

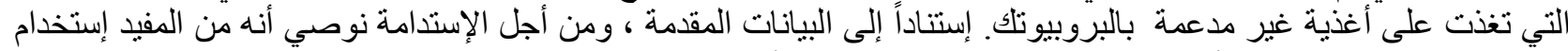
مادة الكايتين كمادة مضافة للأعلاف المستخدمة كغذاء في تربية الأحياء المائية وبصورة خاصة الفية سكة البلطي النيلي. 